\title{
Newspaper advertising for public relations practitioners during the Malaya era 1957-1963
}

Mohammed Fadel Arandas ${ }^{1}$

${ }^{1}$ Affiliation not available

July 9, 2021

\section{Hosted file}

Newspaper advertising for public relations practitioners during the Malaya era 1957-1963.pdf available at https://authorea.com/users/424343/articles/529684-newspaper-advertising-forpublic-relations-practitioners-during-the-malaya-era-1957-1963 